Article

\title{
Adsorption-Enhanced Ceramic Membrane Filtration Using Fenton Oxidation for Advanced Treatment of Refinery Wastewater: Treatment Efficiency and Membrane-Fouling Control
}

\author{
Haotian Mu ${ }^{1}$, Qi Qiu ${ }^{2}$, Renzhen Cheng ${ }^{1}$, Liping Qiu ${ }^{1,3, *}$, Kang Xie ${ }^{1,3}$, Mingchang Gao ${ }^{1}$ and Guicai Liu ${ }^{1,3, *}$ \\ 1 School of Civil Engineering and Architecture, University of Jinan, Jinan 250022, China; \\ muhaotian1997@163.com (H.M.); 18366105822@163.com (R.C.); cea_xiek@ujn.edu.cn (K.X.); \\ gaomc555@163.com (M.G.) \\ 2 School of Water Conservancy and Environment, University of Jinan, Jinan 250022, China; \\ qiuqi_1994@163.com \\ 3 Research Center for Functional Material \& Water Purification Engineering of Shandong Province, \\ Jinan 250022, China \\ * Correspondence: lipingqiu@163.com (L.Q.); cea_liugc@ujn.edu.cn (G.L.)
}

\section{check for} updates

Citation: Mu, H.; Qiu, Q.; Cheng, R.; Qiu, L.; Xie, K.; Gao, M.; Liu, G. Adsorption-Enhanced Ceramic Membrane Filtration Using Fenton Oxidation for Advanced Treatment of Refinery Wastewater: Treatment Efficiency and Membrane-Fouling Control. Membranes 2021, 11, 651. https://doi.org/10.3390/

membranes11090651

Academic Editor: Yingchao Dong

Received: 24 June 2021

Accepted: 21 August 2021

Published: 25 August 2021

Publisher's Note: MDPI stays neutral with regard to jurisdictional claims in published maps and institutional affiliations.

Copyright: (c) 2021 by the authors. Licensee MDPI, Basel, Switzerland. This article is an open access article distributed under the terms and conditions of the Creative Commons Attribution (CC BY) license (https:// creativecommons.org/licenses/by/ $4.0 /)$.

\begin{abstract}
With the development of the refining industry, the treatment of refinery wastewater has become an urgent problem. In this study, a ceramic membrane (CM) was combined with Fenton-activated carbon (AC) adsorption to dispose of refinery wastewater. The effect of the combined process was analyzed using excitation-emission matrix (EEM), ultraviolet-visible (UV-vis) and Fourier transform infrared spectroscopies (FTIR). Compared with direct filtration, the combined process could significantly improve the removal of organic pollution, where the removal rate of the COD and TOC could be $70 \%$ and the turbidity removal rate was above $97 \%$. It was found that the effluent could meet the local standards. In this study, the membrane fouling was analyzed for the impact of the pretreatment on the membrane direction. The results showed that Fenton-AC absorption could effectively alleviate membrane fouling. The optimal critical flux of the combined process was increased from 60 to $82 \mathrm{~L} /\left(\mathrm{m}^{2} \cdot \mathrm{h}\right)$ compared with direct filtration. After running for about $20 \mathrm{~d}$, the flux remained at about $55 \mathrm{~L} /\left(\mathrm{m}^{2} \cdot \mathrm{h}\right)$ and the membrane-fouling resistance was only $1.2 \times 10^{12} \mathrm{~m}^{-1}$. The Hermia model revealed that cake filtration was present in the early stages of the combined process. These results could be of great use in improving the treatment efficiency and operation cycle of refinery wastewater.
\end{abstract}

Keywords: refinery wastewater; ceramic membrane; combined process; membrane-fouling model; membrane-fouling control

\section{Introduction}

With the development of the refining industry, the threat to the environment caused by pollutants [1,2] contained in refinery wastewater has attracted more and more attention [3]. It is difficult for conventional treatments $[4,5]$ to remove pollutants in wastewater such that the local standards are met; therefore, deep treatment processes are essential. Membrane filtration [6-8], activated carbon (AC) adsorption [9-11] and advanced oxidation processes (AOPs) [12-14] have a wide range of applications in deep treatment processes of refinery wastewater due to their unique advantages. However, the treatment efficiency of a single technology is limited [15]. Based on these, it is necessary to design suitable combined processes for the treatment of refinery wastewater.

Compared with a single process, a combined process can remove pollutants in wastewater more effectively and make full use of the advantages of various methods and make up for their shortcomings [16]. After several years of research, some processes [17-24] 
were designed and researched for the treatment of refinery wastewater. According to the previous research, a combined process that consists of an AOP and AC absorption displayed a great effect in the treatment of wastewater $[25,26]$. An AOP has a strong capacity to degrade refractory macromolecular substances into small molecular substances with a fast reaction speed. AC adsorption could be used to remove the pollutants at very low concentration levels in wastewater [27]. Based on these methods, the combined process of AOPs and $\mathrm{AC}$ adsorption has great potential in the treatment of refinery wastewater. However, the application of AOPs and AC would introduce new colloidal substances into the water after processing, and these substances are difficult to separate. To solve this issue, a membrane was introduced.

Membrane separation is one of the most commonly used methods for the deep treatment of refinery wastewater due to its many advantages [28-32]. Through previous research, combining other processes with a membrane in the treatment of refinery wastewater is an effective method for improving the quality of effluent and output [33-35]. However, membrane fouling is the main reason that restricts the application of membranes in wastewater treatment [36]; therefore, controlling membrane fouling is the key to improving the efficiency of membrane filtration [28,32,37,38]. It was found from previous studies [39] that pollutants in wastewater could be removed effectively via pretreatment so that the operating pressure of the subsequent membrane system would be decreased and then membrane fouling was alleviated. Among the possible membranes, it is feasible to combine a ceramic membrane $(\mathrm{CM})$ with an $\mathrm{AOP}$ and $\mathrm{AC}$ adsorption to improve treatment efficiency and reduce membrane fouling [40-45]. The simultaneous combination of CM with an AOP and $\mathrm{AC}$ adsorption is rarely applied in the deep treatment of refinery wastewater; as such, the synergistic effect and membrane-fouling behavior are still unclear, which need further research and verification.

In this study, Fenton oxidation, $\mathrm{AC}$ adsorption and $\mathrm{CM}$ filtration were selected as the main components of a combined process for the deep treatment of refinery wastewater. Single-membrane filtration and a combined process were simultaneously operated to compare and analyze the treatment efficiency and membrane fouling. The model of membrane fouling was built for revealing the mechanism of membrane fouling. This study aimed to provide new insights to improve the efficiency of membrane processes for treating refinery wastewater and alleviate membrane fouling.

\section{Material and Methods}

\subsection{Material and Reagents}

In this study, the CM was provided by the Advanced Ceramic Research Institute of the Zibo High-tech Industrial Development Zone. Its structure is shown in Figure S1. There are channels inside the framework of the membrane module. The feed entered the internal channel through the pores on the membrane's surface and moved to the low-pressure area in the channel due to the suction from the pump. The liquid flowed out of the membrane module assembly through its water outlet and was finally collected. The size was $240 \mathrm{~mm}$ $\times 250 \mathrm{~mm} \times 6 \mathrm{~mm}$, the pore size was $100 \mathrm{~nm}$ and the mechanical strength was $\geq 15 \mathrm{MPa}$. The pure water flux could reach $500 \mathrm{~L} /\left(\mathrm{m}^{2} \cdot \mathrm{h}\right)$ under a pressure of $0.03 \mathrm{MPa}$, which showed a good permeability.

The adsorbent was granular activated carbon with a porosity of $>70$. $\mathrm{Fe}\left(\mathrm{NH}_{4}\right)_{2}\left(\mathrm{SO}_{4}\right)_{2} \cdot 6 \mathrm{H}_{2} \mathrm{O}$ and $\mathrm{H}_{2} \mathrm{O}_{2}$ were the ARs used for the Fenton oxidation and $\mathrm{K}_{2} \mathrm{Cr}_{2} \mathrm{O}_{7}$ used for the analysis of COD was GR. The water used in the experiment was taken from an oil refinery in Shandong.

The feed was from the secondary biochemical effluent of a refinery, where the turbidity of the feed was about $1.78 \mathrm{NTU}$ and the COD was $36 \sim 40 \mathrm{mg} / \mathrm{L}$.

\subsection{The Design of the Experiment}

2.2.1. Direct CM Filtration Experiment

The CM was directly used to treat the refinery wastewater and was operated under the condition of constant pressure filtration. The effluent was collected in a tank to test 
its quality for analysis of the treatment effect. During the operation, the critical flux of the $\mathrm{CM}$ was measured using the flow ladder method and the speed of the pump was controlled to adjust the pressure on both sides of the membrane. The flux was changed every $30 \mathrm{~min}$, and the data of the flux and TMP was recorded every $5 \mathrm{~min}$. Three initial fluxes of 30,60 and $90 \mathrm{~L} /\left(\mathrm{m}^{2} \cdot \mathrm{h}\right)$ during the operation of the filtration were selected and the variation of the flux and TMP was noted to analyze the membrane-fouling behavior.

\subsubsection{Experimental Setup of the Combined Process}

The experimental setup of the combined process is shown in Figure 1. The feed first entered into a regulating tank equipped with a stirring blade, acid addition equipment and a real-time online $\mathrm{pH}$ control device, which was used to adjust the $\mathrm{pH}$ of the wastewater to suitable conditions for Fenton oxidation. The effluent stayed for $5 \mathrm{~min}$, became an outflow and entered into the Fenton reaction tank. The tank was equipped with agitating equipment that maintained $120 \mathrm{r} / \mathrm{min}$ to increase the reaction efficiency. The dosage of the regents was controlled by metering pumps. The $\mathrm{pH}$ condition was controlled at 4.1 and the retention time was $30 \mathrm{~min}$. After the oxidation, the water's $\mathrm{pH}$ was adjusted to 7 by adding $\mathrm{NaOH}$ in the pipe between the Fenton reaction tank and the sedimentation tank, and the water entered the sedimentation tank for precipitating the sludge effectively. The water stayed in the tank for $45 \mathrm{~min}$ and then flowed into the membrane pool in which the activated carbon was directly added to the membrane tank and the concentration was $40 \mathrm{~g} / \mathrm{L}$. After running for $12 \mathrm{~d}$, the activated carbon was changed at a carbon change rate of $4 \% / \mathrm{d}$. Continuous aeration at the bottom of the pool ensured that the activated carbon was suspended in the water, and agitation was used on the surface of the ceramic membrane to reduce the deposition of activated carbon and pollutants on the membrane's surface. Finally, the water was filtered using the CM and collected in a tank for the analysis of the treatment efficiency, where the run time was about $40 \mathrm{~min}$. The changes in flux and TMP were noted every day to study the membrane-fouling behavior.

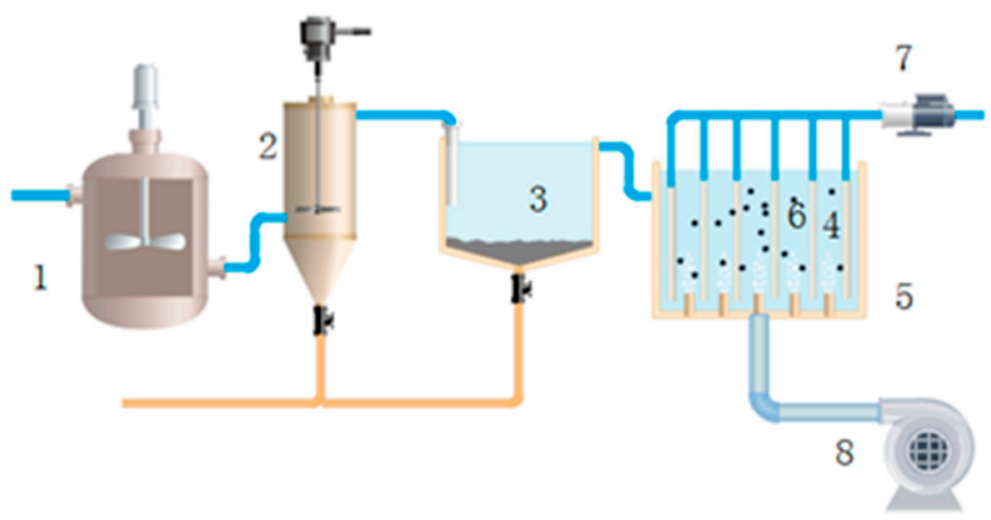

Figure 1. Schematic diagram of the combined process: 1. regulating tank; 2. Fenton reaction tank; 3. sedimentation tank; 4. ceramic membrane; 5. membrane pool; 6. activated carbon powder; 7. production water pump; 8 . blower.

\subsection{The Method of Analysis}

The COD and TOC in the feed were analyzed using the potassium dichromate method and total organic carbon analysis (multi N/C ${ }^{\circledR} 3100$, Jena, Germany), respectively. The turbidity and chromaticity were measured using a turbidity chromaticity meter (2100AN, Hach, CO, USA). The conductivity and $\mathrm{pH}$ were determined using a conductivity analyzer (DDS-307, Lei Ci, Shanghai, China) and a pH meter (S220, Sedrwas, Goettingen, Germany), respectively. A dual-beam UV-visible spectrophotometer (TU-1901, General Analysis of Beijing, China) was used to scan and analyze the pollutants in the feed. The wavelength range was $190 \sim 600 \mathrm{~nm}$, the scanning step was $0.25 \mathrm{~nm}$ and the optical path of the quartz colorimeter was $10 \mathrm{~mm}$. FTIR (NICOLET WAS10, Seymour, Waltham, 
MA, USA) was used to analyze the pollutant categories and organic functional groups in each sample. The resolution was $4 \mathrm{~cm}^{-1}$, the number of scans was 32 and the scanning interval was $4000 \sim 550 \mathrm{~cm}^{-1}$.

A three-dimensional fluorescence spectrum (EEM) was determined using a synchronous absorption three-dimensional fluorescence spectrometer (HORIBA Aqualog ${ }^{\circledR}$, British HORIBA) for the qualitative analysis of each water sample. The excitation spectra (EX) were scanned from 200 to $450 \mathrm{~nm}$ and the emission spectra (EM) were scanned from 240 to $600 \mathrm{~nm}$. The scanning velocity was $50 \mathrm{~nm} / \mathrm{s}$.

\subsection{Membrane-Fouling Analysis}

In the experiment, the membrane pressure on both sides was adjusted according to the speed of the pump and the flux of clear water collected during a certain period was calculated using a stopwatch and a measuring cylinder. The flux was calculated under different pressures according to the following Equation (1):

$$
J=\frac{V}{t S}
$$

where $J$ was the permeate flux $\left(\mathrm{L} /\left(\mathrm{m}^{2} \cdot \mathrm{h}\right)\right), V$ was the filtration volume $(\mathrm{L}), S$ was the membrane area $\left(\mathrm{m}^{2}\right)$ and $t$ was the filtration time $(\mathrm{h})$.

The inherent resistance of the $\mathrm{CM}$ was a basic indicator to measure the membrane performance. The TMP and flux were used as calculation parameters of the inherent resistance. Equation (2) was used for this calculation:

$$
R_{m}=\frac{T M P}{\mu J_{0}}
$$

where $R_{m}$ was the intrinsic membrane resistance, the value of TMP was equal to the membrane pressure on both sides, $J_{0}$ was pure water flux $\left(\mathrm{m}^{3} /\left(\mathrm{m}^{2} \cdot \mathrm{s}\right)\right)$ and $\mu$ was assumed to be the viscosity of water at $25^{\circ} \mathrm{C}\left(0.8937 \times 10^{-3} \mathrm{~N} \cdot \mathrm{s} / \mathrm{m}^{2}\right)$.

Based on Darcy's law, the membrane-fouling resistance was calculated:

$$
\begin{gathered}
J=\frac{T M P}{\mu\left(R_{m}+R_{f}\right)} \\
R=R_{m}+R_{f}
\end{gathered}
$$

where $R$ was the total membrane resistance $\left(\mathrm{m}^{-1}\right)$ and $R_{f}$ was the membrane-fouling resistance $\left(\mathrm{m}^{-1}\right)$.

The critical flux was an important indicator for analyzing the rate of membrane fouling. In the experiment, the critical flux of membrane filtration was measured using the flow ladder method. The flux was changed every $30 \mathrm{~min}$, and the flux and TMP were recorded every $5 \mathrm{~min}$. The critical flux was determined by analyzing the TMP and flux.

\subsection{Membrane-Fouling Model}

The Hermia model was used to fit the membrane-fouling model during the experiment and analyze the type of membrane fouling. The Hermia model contains four types: complete blockage, intermediate blockage, standard blockage and cake filtration. Complete blockage, intermediate blockage and standard blockage can be classified into a block filter and are produced by membrane pore blocking. The cake filtration model is based on the screening effect that particle pollutants carry via a filtrate cake that is formed on the membrane surface. The thickness of the cake and resistance increased with the running time. The specific equation is shown in Table 1. 
Table 1. The equations of the Hermia model: $J^{\prime} \mathrm{S}=p_{0} / p, p$ represented the TMP data at a given time $(\mathrm{kPa}), p_{0}$ represented the initial TMP data when the filtration begins $(\mathrm{kPa}), V s$ was the cumulative filtrate volume and $k^{\prime}$ was the model constant.

\begin{tabular}{cccc}
\hline Model & Equations & Model & Equations \\
\hline Cake filtration & $\frac{1}{J_{s}^{\prime}}=1+k^{\prime} V_{s}$ & Standard blockage & $J_{s}^{\prime \frac{1}{2}}=1-\frac{k^{\prime}}{2} V_{S}$ \\
Intermediate blockage & $\ln J_{S}^{\prime}=-k^{\prime} V_{s}$ & Complete blockage & $J_{S}^{\prime}=1-k^{\prime} V_{s}$ \\
\hline
\end{tabular}

\section{Results and Discussion}

Separate membrane filtration and combined processes were adopted to treat the feed. By analyzing the removal effect of pollutants in the wastewater and membranefouling behavior, the treatment mechanism of the combined process and the reason for the membrane fouling were obtained.

\subsection{Treatment Efficiency}

\subsubsection{The Removal of Organic Pollutants and the Turbidity}

The removal effect of organic pollutants in the refinery wastewater can be reflected using the TOC and COD. Under the condition of direct filtration, the removal rate of the COD and TOC was about $20 \%$ and $14 \%$, respectively, and the concentrations of the COD and TOC were $28 \sim 30 \mathrm{mg} / \mathrm{L}$ and about $8.5 \mathrm{mg} / \mathrm{L}$ in the effluent, respectively (as shown in Figure 2). It was found that the removal rate of organisms using direct membrane filtration was stable but relatively low. This might have been because the organics in refinery wastewater were mostly dissolved [28]. After the filtration, the suspended particles and oil with small grains were retained but a large number of organics could go through the pores, which resulted in the low removal rate observed.

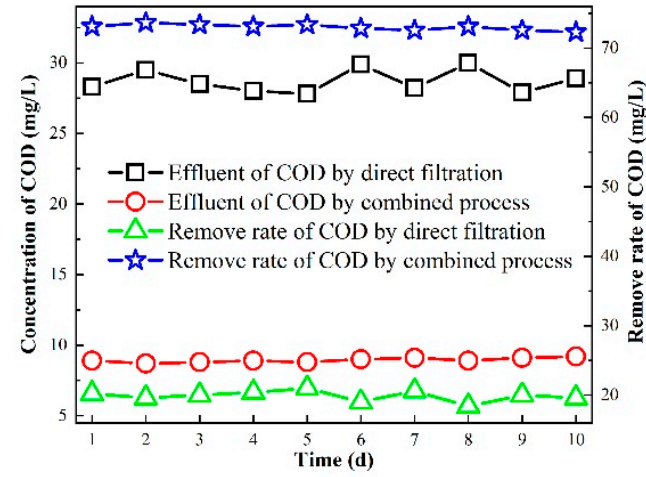

(a)

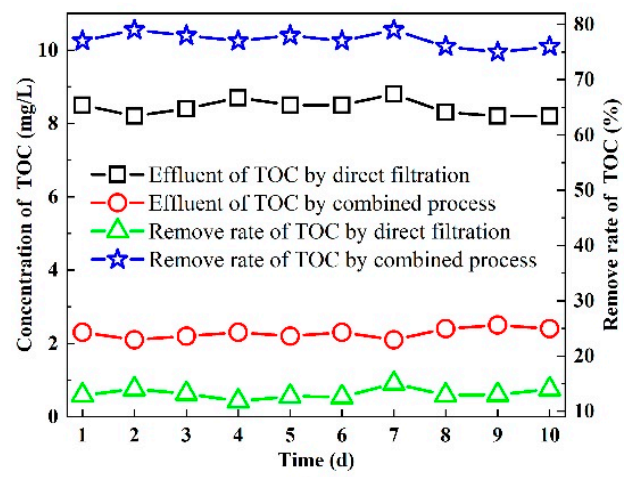

(h)

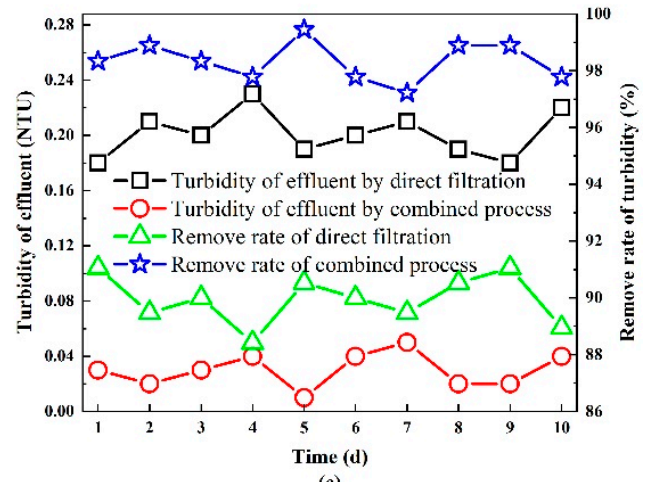

(c)

Figure 2. Removal of organic pollutants and turbidity using direct filtration and combined processes: (a) the removal of TOC from the refinery wastewater; (b) the removal of COD from the refinery wastewater; (c) the removal of turbidity from the refinery wastewater. 
Compared with direct filtration, although the treatment effect of the organics using the combined process fluctuated slightly, the removal rate of the COD and TOC remained above $70 \%$ under the combined process. The system operated stably and the COD and TOC in the effluent were lower than $10 \mathrm{mg} / \mathrm{L}$ and $2 \sim 3 \mathrm{mg} / \mathrm{L}$, respectively. The result met the quality requirements. It was speculated that the process of Fenton oxidation and AC adsorption could effectively improve the removal effect of CM on organic pollutants in refinery wastewater.

The turbidity in the refinery wastewater was high; therefore, it should be further analyzed. The turbidity removal effect is shown in Figure 2c. It can be seen that the direct filtration using the $\mathrm{CM}$ had a good effect on removing the turbidity, where the removal rate could reach about $90 \%$. The turbidity in the feed could be reduced from 1.9 to 0.2 (NTU) after the filtration and the effluent could meet the local standard. The result showed that the concentration of the turbidity in the refinery wastewater could be effectively reduced by the direct filtration of the CM. Some research [41] revealed the treatment effect of CM on wastewater with different turbidity levels. It was indicated that more than $98 \%$ of the turbidity was removed during the filtration of CM under all the tested conditions. Meanwhile, the removal effect of turbidity using the combined system showed that the turbidity removal rate was above $97 \%$ and the turbidity in the effluent was lower than 0.05 NTU under the tested conditions. Therefore, compared with direct filtration, the removal of turbidity could be further improved using the combined process.

\subsubsection{Fluorescence EEM Spectra}

EEM was widely used as a useful method for the analysis of pollutant composition in water [46-50]. In this study, EEM was used to analyze the composition in the refinery wastewater at different stages. It was found that the EEM spectra could be divided into two regions: $\lambda_{\mathrm{EX}} / \lambda_{\mathrm{EM}}=245 \mathrm{~nm} / 385 \mathrm{~nm}$ and $\lambda_{\mathrm{EX}} / \lambda_{\mathrm{EM}}=305 \mathrm{~nm} / 385 \mathrm{~nm}$ (as shown in Figure 3a). According to previous studies [51,52], the peaks might be related to alkanes and polycyclic aromatic hydrocarbons, such as tyrosine and tryptophan. As shown in Figure 3b, the peak intensities of the two regions showed no obvious change. It was noted that most organic matter, such as aromatic compounds, was rarely intercepted using direct membrane filtration. The organic pollutants in the refinery wastewater could be significantly reduced using Fenton oxidation (shown from Figure 3c), where the peak removal rates at $245 \mathrm{~nm} / 385 \mathrm{~nm}$ and $305 \mathrm{~nm} / 385 \mathrm{~nm}$ were above 95\% and 94\%, respectively. The locations of the peaks drifted, which meant that macromolecular substances, such as polycyclic aromatic hydrocarbons, turned into substances with a lower molecular weight, such as fulvic acid. To further explore the removal mechanism, the removal effect was researched via dosing with PFS for flocculation alone (as shown in Figure 3d). The result indicated that the removal of fluorescent substances in the refinery wastewater using the Fenton system was a synergistic process of flocculation and oxidation, and the removal rate was relatively low when using flocculation alone, which indicated that the oxidation played a leading role. The area of the peak was further decreased after the AC absorption (as shown in Figure 3e), where the peak was below 50 and the removal rate was above 96\% after the absorption. It was supposed that some small molecules, such as fulvic acid and humic acid, were thoroughly adsorbed on the surface or in the pores of AC during the process [53]. After the pretreatment of Fenton oxidation and AC absorption, the water was filtrated using CM and, as a result, the pollutants in the feed were completely removed using the combined process (as shown in Figure 3f). Therefore, compared with the result of direct filtration, the treatment effect of refinery wastewater using the combined process was better. 

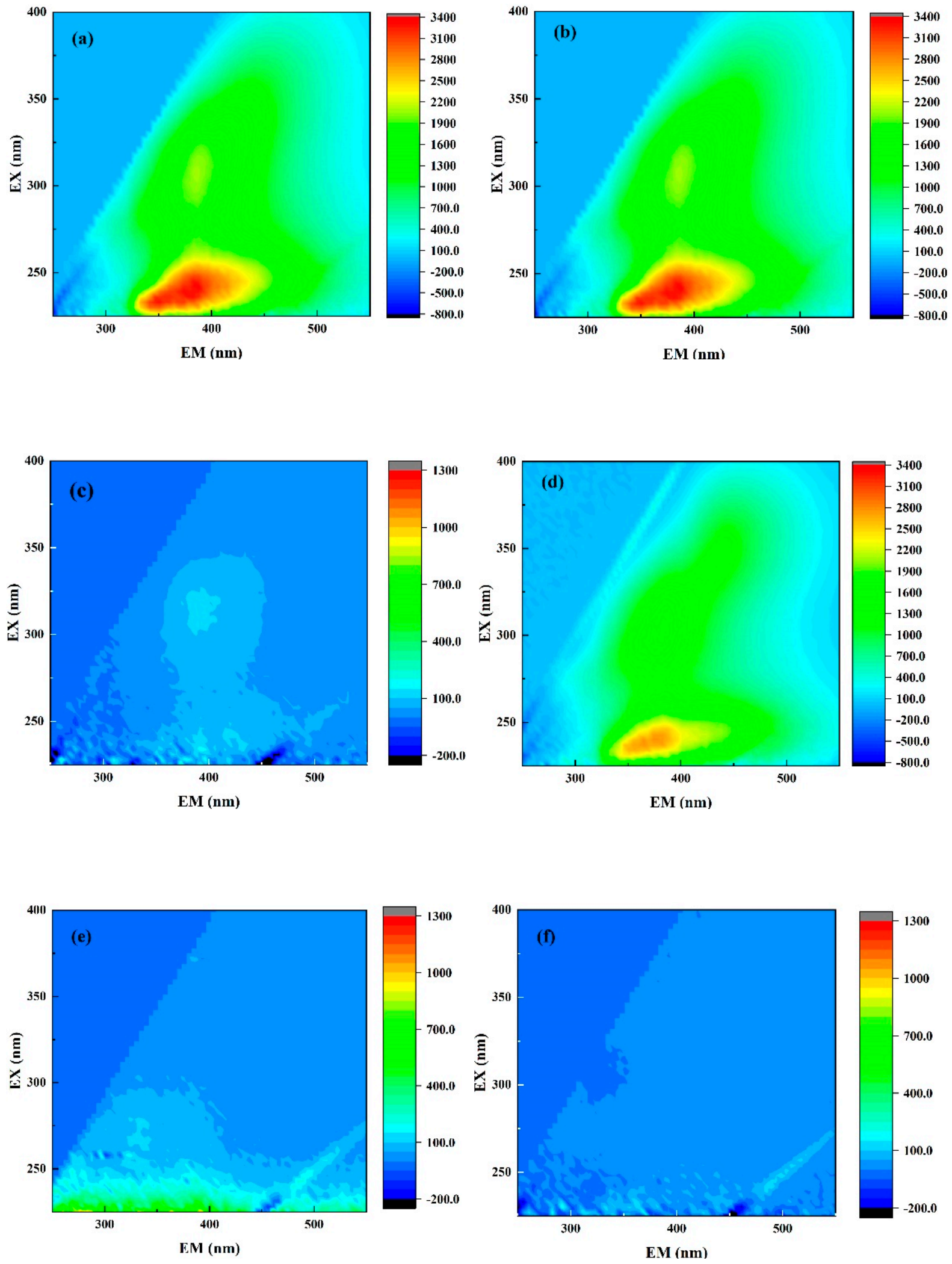

Figure 3. EEM diagram of water: (a) feed; (b) single TCM; (c) after Fenton oxidation; (d) dosing Fe ${ }^{2+}$ for coagulation; (e) absorbed by AC; (f) effluent. The excitation spectra (EX) were scanned from 200 to $450 \mathrm{~nm}$ and the emission spectra (EM) were scanned from 240 to $600 \mathrm{~nm}$. The scanning velocity was $50 \mathrm{~nm} / \mathrm{s}$. 


\subsubsection{The UV-vis and FTIR Analyses}

UV-vis is an important method for the analysis of dissolved organic matter in wastewater. The method was used in many studies to analyze the concentration of COD in wastewater and the transformation of organic matter [54,55]. As shown in Figure 4, the change of organics in the refinery wastewater after filtration was not obvious from the UV-vis, indicating that direct membrane filtration was not ideal for removing the pollutants in the refinery wastewater. After the Fenton oxidization, the absorbance for wavelengths ranging from 190 to $230 \mathrm{~nm}$ was effectively reduced, while the location of the peak at $220 \mathrm{~nm}$ changed a little and the peak at $202 \mathrm{~nm}$ was red-shifted to $210 \mathrm{~nm}$. This indicated that aromatic compounds could be effectively reduced using Fenton oxidation. It can be seen from Figure 4 that the absorbance (Abs) values at all wavelengths decreased after the absorption by the $\mathrm{AC}$, indicating that the small pollutants produced after the Fenton oxidation could be removed by the AC. In the end, the absorbance of the effluent treated using the combined process was significantly reduced compared with the direct membrane filtration, which indicates that the pretreatment of Fenton oxidation and AC adsorption could promote the removal effect of the $\mathrm{CM}$ for organics in the refinery wastewater.
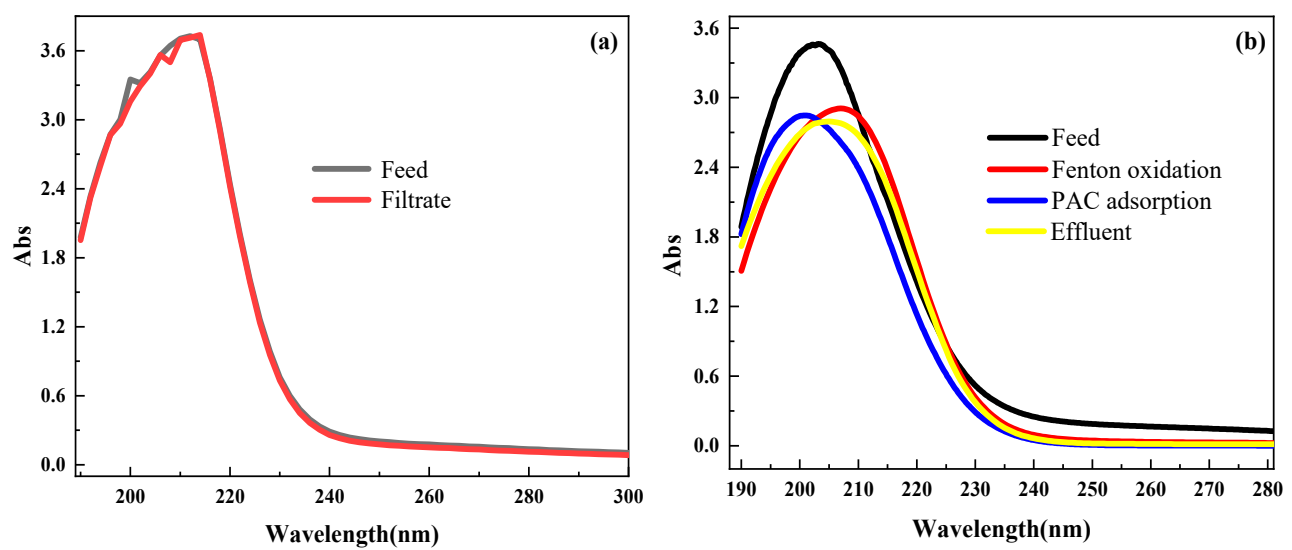

Figure 4. The changes in UV-vis for varied effluents: (a) the changes in UV-vis during the direct filtration using the ceramic membrane; (b) the changes of UV-vis in each phase of the combined process. The wavelength range was $190 \sim 600 \mathrm{~nm}$, the scanning step was $0.25 \mathrm{~nm}$ and the optical path of the quartz colorimeter was $10 \mathrm{~mm}$.

FTIR is an effective method for analyzing the categories of pollutants and functional groups of organic compounds in water [56]. Through FTIR analysis, pollutants in water can be effectively identified and the rules of transformation about organic compounds under different treatment conditions can be analyzed. The feed and effluent of the different stages, including Fenton oxidation, AC absorption and the membrane, were each analyzed using FTIR (Figure 5). As shown in Figure 5, after the Fenton oxidation, the peak in the range from $1640 \mathrm{~cm}^{-1}$ to $1141 \mathrm{~cm}^{-1}$ decreased, which indicated that the Fenton oxidization could effectively reduce the concentration of sulfonic acid ester, amines and aromatic pollutants, and the result was consistent with the results of the EEM, where the peaks at $1384 \mathrm{~cm}^{-1}$ and $1141 \mathrm{~cm}^{-1}$ were also significantly lower compared with the feed. We found that a good treatment effect on sulfate lipids and amines could be achieved by Fenton oxidation. The peaks at $1640 \mathrm{~cm}^{-1}$ and $3416 \mathrm{~cm}^{-1}$ significantly decreased after the AC absorption, where fulvic acid and other small molecule substances in the refinery wastewater could be removed. Moreover, the concentration of amine compounds in the effluent was further reduced by the combined process of Fenton oxidation and AC absorption. However, after oxidation, a new peak appeared at $1270 \mathrm{~cm}^{-1}$, which might have been the anti-symmetric stretching vibration of the $\mathrm{SO}_{3}$ of the sulfate $\mathrm{RO}^{-} \mathrm{SO}_{2}-\mathrm{O}-$. After the analysis, it was determined that the $\mathrm{R}$ groups in $\mathrm{R}_{1} \mathrm{O}-\mathrm{SO}_{2}-\mathrm{OR}_{2}$ in the sulfate were oxidized to form the sulfate, and the sulfate was difficult to completely remove using the process 
of AC adsorption. It can be seen from Figure 5 that the sulfate was mainly removed using CM filtration. It was confirmed from the FTIR result that the molecular substances, such as aromatic pollutants, could be decomposed to low-molecular-weight organic matter and inorganic matter, which was further removed using AC absorption and CM filtration, and the treatment effect of the combined process was better than the direct membrane filtration.

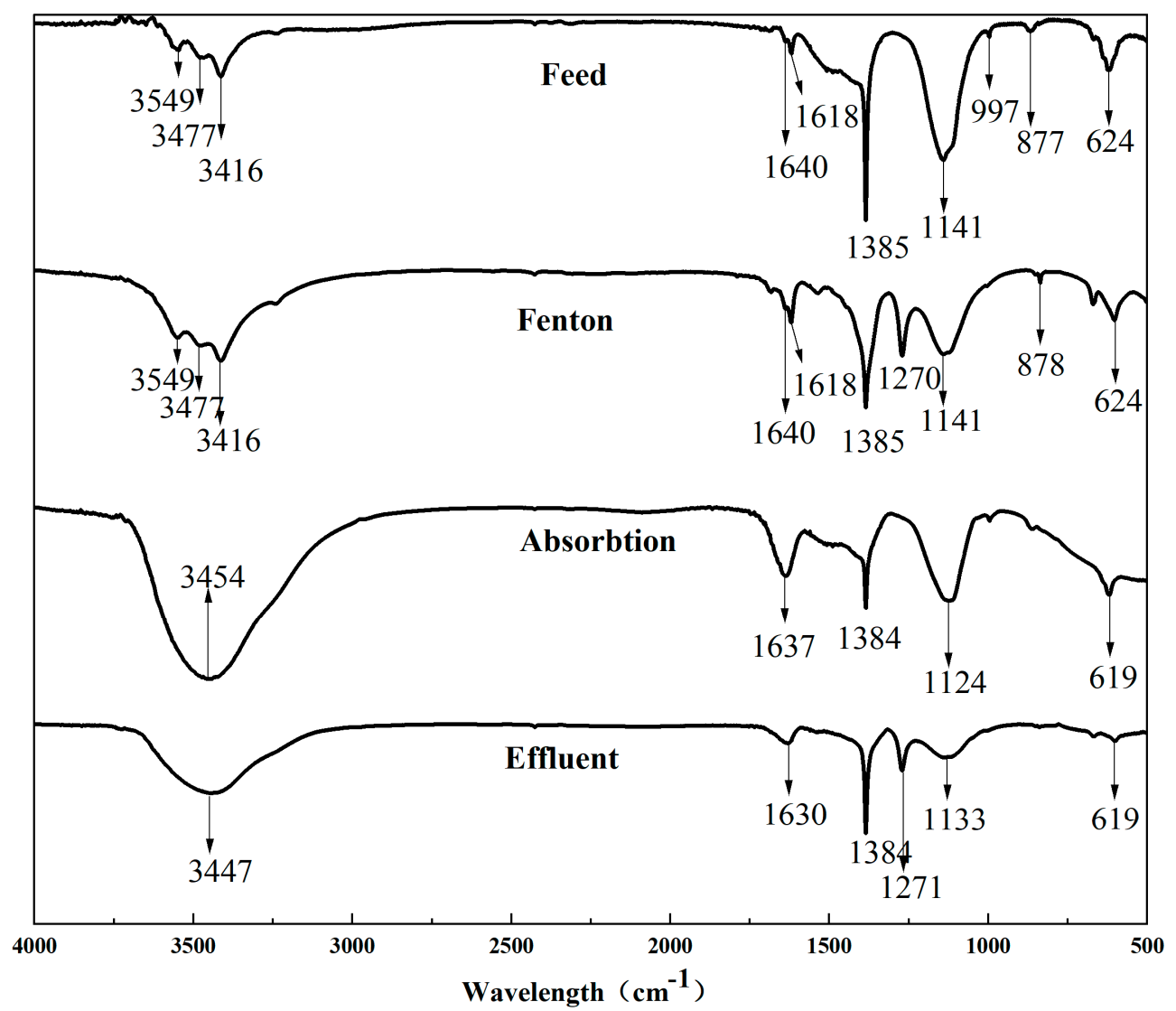

Figure 5. The changes in FTIR for varied effluents: the resolution was $4 \mathrm{~cm}^{-1}$, the number of scans was 32 and the scanning interval was $4000-550 \mathrm{~cm}^{-1}$.

\subsection{Membrane-Fouling Behavior}

\subsubsection{Critical Flux}

The proper critical flux can ensure the stable operation of the membrane system. In this study, the critical flux was used to measure the operating efficiency [57] and reflect membrane fouling.

The TMP was gradually improved by changing the speed of the pump to confirm the critical flux in the operations of the direct filtration and the combined process. The result is shown in Figure 6. During the operation of direct filtration, the flux and $T M P$ both increased when the speed of the pump increased. In the initial stage of the operation, they remained relatively stable after being changed. When the speed increased to $80 \mathrm{r} / \mathrm{min}$, the flux had a small downtrend $\left(80 \mathrm{to} 76 \mathrm{~L} /\left(\mathrm{m}^{2} \cdot \mathrm{h}\right)\right)$ within a short time. As the speed increased, the downtrend became more and more obvious with the faster growth of the TMP. It was seen that the flux increased first and then decreased with the continuous increase in TMP after the speed exceeded $60 \mathrm{r} / \mathrm{min}$. According to the definition in [58], it was indicated that when the $\mathrm{CM}$ was used alone for filtration, the critical flux was $60 \mathrm{~L} /\left(\mathrm{m}^{2} \cdot \mathrm{h}\right)$ and the corresponding $T M P$ was $15 \mathrm{kPa}$. 


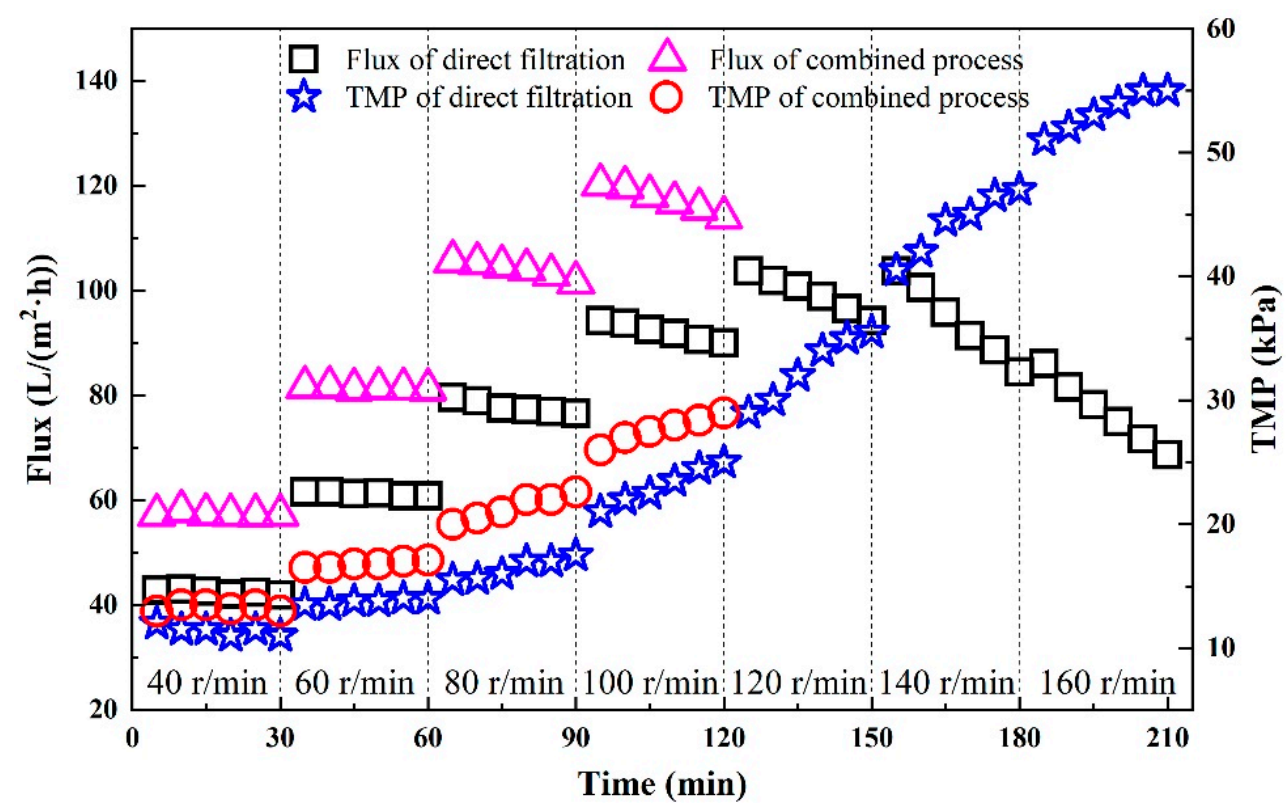

Figure 6. The changes in the critical flux and TMP: the critical flux of the membrane filtration was measured using the flow ladder method. The flux was changed every $30 \mathrm{~min}$, and the flux and TMP difference in this period were recorded every $5 \mathrm{~min}$.

As for the combined process (shown in Figure 6), when the TMP was $14 \mathrm{kPa}$, the critical flux could reach $57 \mathrm{~L} /\left(\mathrm{m}^{2} \cdot \mathrm{h}\right)$ and the flux and TMP were relatively stable. When the TMP increased to $16 \mathrm{kPa}$ with the increase in speed, the critical flux reached $82 \mathrm{~L} /\left(\mathrm{m}^{2} \cdot \mathrm{h}\right)$. As the speed continued to increase, the TMP began to rise within a short time and the flux decreased gradually. Therefore, the critical flux of the CM in the combined process was $82 \mathrm{~L} /\left(\mathrm{m}^{2} \cdot \mathrm{h}\right)$ and the corresponding $T M P$ was $16 \mathrm{kPa}$.

Compared with the direct filtration, the critical flux during the combined process was increased by about $37 \%$, which meant that a greater water yield was created using the combined process. The reason for this might have been that the large molecules of organic matter in the wastewater were decomposed by the pretreatment of Fenton adsorption into small molecules, such as sulfate. These were more likely to pass through the membrane pores, which could effectively alleviate membrane fouling. Therefore, the pretreatment of Fenton absorption improved the flux, reduced the pollution in the water and effectively slowed membrane fouling.

\subsubsection{Flux Decline and Membrane Resistance}

During operation, membrane fouling can appear due to concentration polarization, cake layering and pore blocking [59], and it is inevitable. In this study, the reason for the membrane-fouling behavior during operation was further analyzed and the influences of pretreatment for membrane filtration were researched.

In order to further analyze the membrane-fouling behavior during direct filtration, the changes in flux and TMP under different conditions of initial flux (Figure 7) were analyzed. As shown in Figure $7 \mathrm{a}, \mathrm{b}$, when the initial flux was $30 \mathrm{~L} /\left(\mathrm{m}^{2} \cdot \mathrm{h}\right)$, the flux of the $\mathrm{CM}$ and the TMP changed rapidly. The flux decreased from 30 to $18 \mathrm{~L} /\left(\mathrm{m}^{2} \cdot \mathrm{h}\right)$ during the first $500 \mathrm{~min}$ of operation and the TMP increased from 17 to $51 \mathrm{kPa}$. Therefore, the $\mathrm{CM}$ was polluted rapidly during this time and the same phenomenon occurred in the conditions where the initial fluxes of 60 and $90 \mathrm{~L} /\left(\mathrm{m}^{2} \cdot \mathrm{h}\right)$ were used. When the initial flux was higher, the decrease in flux was more obvious. During the operation, intermittent operation mode (operating for $12 \mathrm{~h}$ and intermission for $12 \mathrm{~h}$ ) was adopted, where the flux increased and the TMP decreased synchronously after the intermission. 

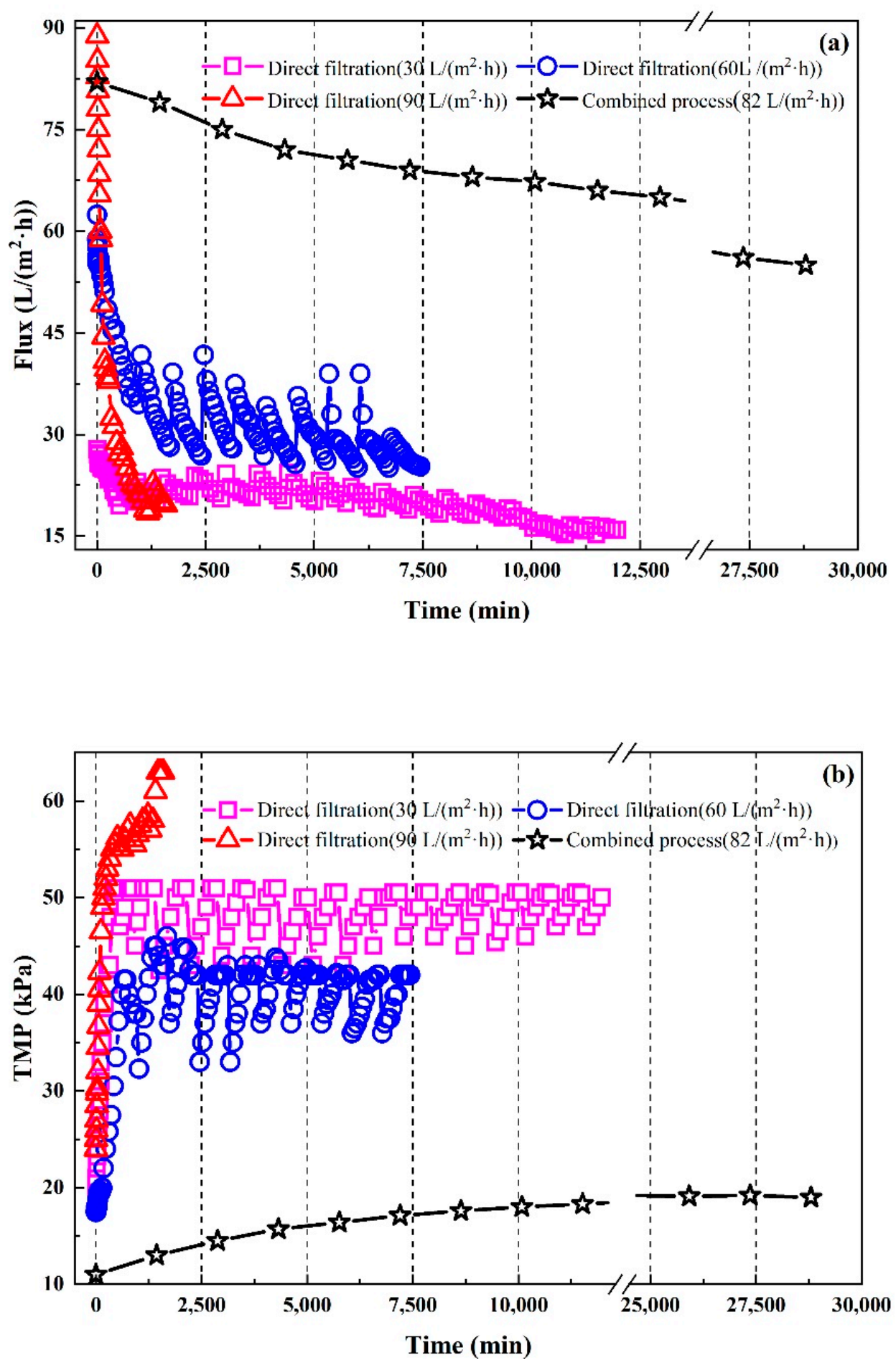

Figure 7. Changes in the flux and TMP of the ceramic membrane: (a) flux changes during the membrane filtration and combined processes with different initial fluxes; (b) changes in the TMP in the membrane filtration and combined processes with different initial fluxes: during the process of direct filtration, the data was obtained by adjusting the peristaltic pump speed $(60,80$ or $140 \mathrm{r} / \mathrm{min})$ to adjust the bilateral membrane pressure and a stopwatch and measuring cylinder were used to calculate the flux of water passing through the membrane during a certain time, where the flux was calculated using Equation (1). The initial flux of the combined process was selected according to Section 3.2.1 and the calculation method during the process was the same as for direct filtration.

The observed phenomena might have been caused by cake filtration and concentration polarization on the membrane's surface in the initial phase of operation. When 
membrane fouling was mainly a cake layer, intermittent operation mode could reduce the accumulation of cake on the membrane surface and improve the operating flux. With the extension of the running time, the change in the flux and TMP tended toward being stable. This might have been because the membrane fouling was dominated by membrane hole obstruction. When the reason for the membrane fouling was membrane hole obstruction, the intermittent operation mode had little influence on the TMP and flux. When the initial flux was $60 \mathrm{~L} /\left(\mathrm{m}^{2} \cdot \mathrm{h}\right)$, the final flux fluctuated in the range from 25 to $30 \mathrm{~L} /\left(\mathrm{m}^{2} \cdot \mathrm{h}\right)$ and the $T M P$ varied from 45 to $55 \mathrm{kPa}$, which was higher than in the other condition. This result shows that the membrane fouling was controlled the best under these conditions. This was because the initial flux of $60 \mathrm{~L} /\left(\mathrm{m}^{2} \cdot \mathrm{h}\right)$ was the critical flux of the CM [60].

For the combined process, the changes in the flux and TMP are shown in Figure 7a,b. It can be seen that in the first 5 days, the flux decreased rapidly but the TMP increased relatively slowly, where it was only $6 \mathrm{kPa}$ higher than the initial operation pressure. Eventually, the TMP stabilized at about $19 \mathrm{kPa}$. At the later stage of operation, the flux decline also slowed down gradually. After 20 days, the flux remained at about $55 \mathrm{~L} /\left(\mathrm{m}^{2} \cdot \mathrm{h}\right)$. By comparing this with the result of the FTIR, membrane fouling was further analyzed. According to the analysis, we concluded that Fenton oxidation could effectively reduce the amount of aromatic compounds in the water, which were considered to be the main reason for the membrane fouling [61]. These were removed or oxidized into molecules with smaller molecular weights [62-64]. Therefore, compared with direct filtration, the combined process could slow down the phenomenon of flux decline and extended the operating cycle.

To further analyze the flux and TMP under three different initial fluxes $\left(30,60\right.$ and $\left.90 \mathrm{~L} /\left(\mathrm{m}^{2} \cdot \mathrm{h}\right)\right)$, the membrane resistance under three working conditions was analyzed (Figure S1). At the beginning of the operation, the membrane resistance under the three working conditions showed a large increase immediately and then tended to be stable, which was similar to the results shown above. When the initial flux was $60 \mathrm{~L} /\left(\mathrm{m}^{2} \cdot \mathrm{h}\right)$, the membrane resistance rose the slowest and the final membrane resistance was the lowest. This result further showed that the CM was polluted quickly at the beginning, and under operating conditions with a critical flux, the membrane life cycle could be extended $[65,66]$.

As for the combined process (Figure S2), in the early stage, the membrane resistance was only $4.5 \times 10^{11} \mathrm{~m}^{-1}$, and with the increase in running time, the membrane resistance increased slowly. After 20 days, the membrane resistance increased to only $1.2 \times 10^{12} \mathrm{~m}^{-1}$, which was far lower than the resistance found for direct filtration. This means that the membrane in the operation of the combined process had a better anti-pollution performance.

\subsection{Membrane-Fouling Model}

Membrane fouling is the main reason to restrict the operation of a membrane system, which can be further understood using model fitting. According to the conclusion above, different types of membrane fouling were created by different initial fluxes during the operating conditions when using direct filtration. The Hermia model was used to fit the model of membrane fouling and the result can be seen in Figure 8. The result showed that when the initial flux was 30,60 and $90 \mathrm{~L} /\left(\mathrm{m}^{2} \cdot \mathrm{h}\right)$, the types of membrane fouling were more consistent with the models of cake filtration, complete blocking and cake filtration, respectively. This indicated that the cake layer on the membrane surface gradually formed in the stage of critical flux $[67,68]$. For the combined process, the result can be seen in Figure $8 \mathrm{~d}$. The result was more consistent with the cake layer model in the initial stage of operation, meaning that the cake layer was formed on the surface of the CM during this stage. This phenomenon might have been caused by the AC that was absorbed on the membrane surface because of the pumping action of the pump. In the subsequent stage of constant pressure filtration, although the cake layer had been formed, the fitting degree of the model of cake filtration was poor. It was speculated that the membrane fouling was dominated by various types of membrane fouling. This might have been because the small molecules that were created due to the decomposition of the pollutants in the wastewater by AOPs entered into the holes of the membrane. 

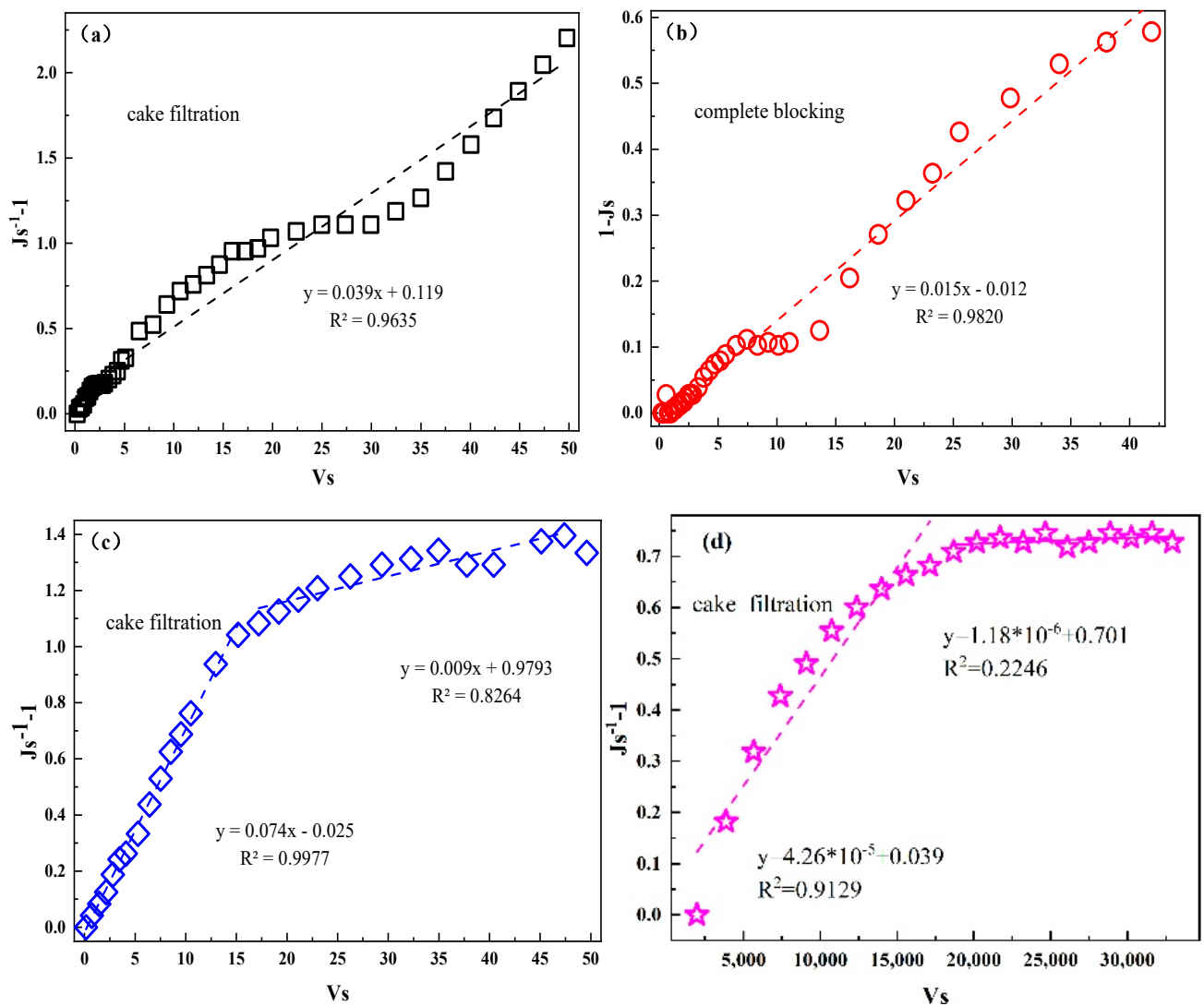

Figure 8. The membrane-fouling models with different initial fluxes were fitted with separate membrane filtration conditions: (a) the model with an initial flux of $30 \mathrm{~L} /\left(\mathrm{m}^{2} \cdot \mathrm{h}\right)$; (b) the model with an initial flux of $60 \mathrm{~L} /\left(\mathrm{m}^{2} \cdot \mathrm{h}\right)$; (c) the model with an initial flux of $90 \mathrm{~L} /\left(\mathrm{m}^{2} \cdot \mathrm{h}\right) ;(\mathbf{d})$ membrane-fouling model fitting for the combined process.

\section{Conclusions}

In this study, a combined process involving an $\mathrm{AOP}, \mathrm{AC}$ absorption and $\mathrm{CM}$ filtration for the treatment of refinery wastewater was systematically built. The treatment effect and membrane-fouling behavior of direct filtration and the combined process on refinery wastewater were compared and analyzed. According to the results, the following conclusions were found:

1. The TOC, COD and turbidity could be significantly improved using the combined process. This was because some organic macromolecular matter, such as aromatic compounds in the wastewater, was effectively decomposed using Fenton oxidationand finally removed using the AC and CM.

2. Compared with direct membrane filtration, it was found that the optimal critical flux of the CM could be significantly increased and the membrane fouling could be effectively alleviated using the combined process. According to the analysis, the $\mathrm{AOP}$ and $\mathrm{AC}$ absorption could decompose the macromolecular substances in the wastewater into small molecular substances, which passed through the pores of the membrane easier.

3. The model of membrane fouling in the combined process was more consistent with the cake layer model in the initial stage and the membrane fouling might have been dominated by various types of membrane fouling in the subsequent stages. 
Supplementary Materials: The following are available online at https: / www.mdpi.com/article/ 10.3390/membranes11090651/s1, Figure S1: The structure of the membrane module, Figure S2: Membrane resistance of $\mathrm{CM}$ in the operation of direct filtration and combined process: The membrane fouling resistance was calculated by Equations (1)-(4).

Author Contributions: Conceptualization, H.M., L.Q. and G.L.; methodology, H.M. and G.L.; software, H.M. and Q.Q.; validation, H.M., L.Q. and G.L.; formal analysis, H.M. and R.C.; investigation, K.X. and M.G.; resources, H.M. and Q.Q.; data curation, G.L. and R.C.; writing-original draft preparation, H.M.; writing-review and editing, L.Q. and G.L.; visualization, H.M.; supervision, L.Q. and G.L.; project administration, L.Q. and G.L.; funding acquisition, L.Q. and G.L. All authors read and agreed to the published version of the manuscript.

Funding: This study was financially supported by the National Natural Science Foundation of China (grant Nos. 51678276 and 51808257), the funding program of 20 policies for universities in Jinan (2018GXRC020), Natural Science Foundation of Shandong Province (ZR2020ME227), the Scientific and Technological Research Project of Science and Technology Department of Shandong Province (2019GSF109083), the National Natural Science Foundation of China (no. 51808257) and the Scientific and Technological Research Project of Science and Technology Department of Shandong Province (2019GSF109083).

Institutional Review Board Statement: The study did not involve humans or animals.

Informed Consent Statement: Not applicable.

Data Availability Statement: Not applicable.

Acknowledgments: We are grateful to the National Natural Science Foundation of China and the Shandong Science and Technology Department for their strong support.

Conflicts of Interest: The authors declare no conflict of interest.

\section{References}

1. Liu, Y.; Han, F.; Liu, W.; Cui, X.; Luan, X.; Cui, Z. Process-based volatile organic compound emission inventory establishment method for the petroleum refining industry. J. Clean. Prod. 2020, 263, 121609. [CrossRef]

2. Santos, B.; Galinha, C.F.; Crespo, J.G.; Santos, M.A.; Velizarov, S. Prediction of polar oil and grease contamination levels in refinery wastewater through multivariate statistical modeling. Sep. Purif. Technol. 2013, 119, 51-57. [CrossRef]

3. Osin, O.A.; Yu, T.Y.; Lin, S.J. Oil refinery wastewater treatment in the Niger Delta, Nigeria: Current practices, challenges, and recommendations. Environ. Sci. Pollut. Res. 2017, 24, 22730-22740. [CrossRef]

4. Yu, L.; Han, M.; He, F. A review of treating oily wastewater. Arab. J. Chem. 2017, 10, S1913-S1922. [CrossRef]

5. Kriipsalu, M.; Marques, M.; Nammari, D.R.; Hogland, W. Bio-treatment of oily sludge: The contribution of amendment material to the content of target contaminants, and the biodegradation dynamics. J. Hazard. Mater. 2007, 148, 616-622. [CrossRef] [PubMed]

6. Abadi, S.R.H.; Sebzari, M.R.; Hemati, M.; Rekabdar, F.; Mohammadi, T. Ceramic membrane performance in microfiltration of oily wastewater. Desalination 2011, 265, 222-228. [CrossRef]

7. Abbasi, M.; Mirfendereski, M.; Nikbakht, M.; Golshenas, M.; Mohammadi, T. Performance study of mullite and mullite-alumina ceramic MF membranes for oily wastewaters treatment. Desalination 2010, 259, 169-178. [CrossRef]

8. Zhu, X.; Tu, W.; Wee, K.-H.; Bai, R. Effective and low fouling oil/water separation by a novel hollow fiber membrane with both hydrophilic and oleophobic surface properties. J. Membr. Sci. 2014, 466, 36-44. [CrossRef]

9. Boehler, M.; Zwickenpflug, B.; Hollender, J.; Ternes, T.; Joss, A.; Siegrist, H. Removal of micropollutants in municipal wastewater treatment plants by powder-activated carbon. Water Sci. Technol. 2012, 66, 2115-2121. [CrossRef] [PubMed]

10. Ben Hariz, I.; Al Ayni, F.; Monser, L. Removal of sulfur compounds from petroleum refinery wastewater through adsorption on modified activated carbon. Water Sci. Technol. 2014, 70, 1376-1382. [CrossRef]

11. Hami, M.L.; Al-Hashimi, M.A.; Al-Doori, M.M. Effect of activated carbon on BOD and COD removal in a dissolved air flotation unit treating refinery wastewater. Desalination 2007, 216, 116-122. [CrossRef]

12. Candido, L.; Ponciano Gomes, J.A.C.; Medaber Jambo, H.C. Electrochemical Treatment of Oil Refinery Wastewater for $\mathrm{NH}_{3}-\mathrm{N}$ and COD Removal. Int. J. Electrochem. Sci. 2013, 8, 9187-9200.

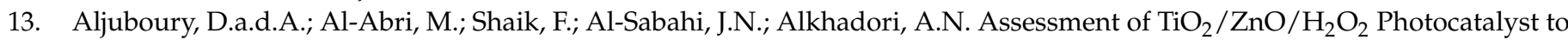
treat wastewater from oil refinery within visible light circumstances. S. Afr. J. Chem. Eng. 2020, 35, 69-77. [CrossRef]

14. Coelho, A.; Castro, A.V.; Dezotti, M.; Sant'Anna, G.L. Treatment of petroleum refinery sourwater by advanced oxidation processes. J. Hazard. Mater. 2006, 137, 178-184. [CrossRef] [PubMed]

15. Estrada-Arriaga, E.B.; Zepeda-Aviles, J.A.; García-Sánchez, L. Post-treatment of real oil refinery effluent with high concentrations of phenols using photo-ferrioxalate and Fenton's reactions with membrane process step. Chem. Eng. J. 2016, 285, 508-516. [CrossRef] 
16. Li, H.; Yu, P.; Luo, Y. Fouling mechanisms and primary foulant constituents in reverse osmosis membrane reclamation of a petrochemical secondary effluent. Desalination Water Treat. 2015, 54, 3200-3210. [CrossRef]

17. Bhagawan, D.; Poodari, S.; Golla, S.; Himabindu, V.; Vidyavathi, S. Treatment of the petroleum refinery wastewater using combined electrochemical methods. Desalination Water Treat. 2016, 57, 3387-3394. [CrossRef]

18. Diya'uddeen, B.H.; Rahim Pouran, S.; Abdul Aziz, A.R.; Nashwan, S.M.; Wan Daud, W.M.A.; Shaaban, M.G. Hybrid of Fenton and sequencing batch reactor for petroleum refinery wastewater treatment. J. Ind. Eng. Chem. 2015, 25, 186-191. [CrossRef]

19. Souza, B.M.; Cerqueira, A.C.; Sant'Anna, G.L.; Dezotti, M. Oil-Refinery Wastewater Treatment Aiming Reuse by Advanced Oxidation Processes (AOPs) Combined with Biological Activated Carbon (BAC). Ozone Sci. Eng. 2011, 33, 403-409. [CrossRef]

20. Rueda-Márquez, J.J.; Levchuk, I.; Salcedo, I.; Acevedo-Merino, A.; Manzano, M.A. Post-treatment of refinery wastewater effluent using a combination of AOPs $\left(\mathrm{H}_{2} \mathrm{O}_{2}\right.$ photolysis and catalytic wet peroxide oxidation) for possible water reuse. Comparison of low and medium pressure lamp performance. Water Res. 2016, 91, 86-96. [CrossRef]

21. Nogueira, A.A.; Bassin, J.P.; Cerqueira, A.C.; Dezotti, M. Integration of biofiltration and advanced oxidation processes for tertiary treatment of an oil refinery wastewater aiming at water reuse. Environ. Sci. Pollut. Res. 2016, 23, 9730-9741. [CrossRef]

22. Zhang, S.; Zheng, J.; Chen, Z. Combination of ozonation and biological aerated filter (BAF) for bio-treated coking wastewater. Sep. Purif. Technol. 2014, 132, 610-615. [CrossRef]

23. Hernández-Francisco, E.; Peral, J.; Blanco-Jerez, L.M. Removal of phenolic compounds from oil refinery wastewater by electrocoagulation and Fenton/photo-Fenton processes. J. Water Process Eng. 2017, 19, 96-100. [CrossRef]

24. Saber, A.; Mortazavian, S.; James, D.E.; Hasheminejad, H. Optimization of Collaborative Photo-Fenton Oxidation and Coagulation for the Treatment of Petroleum Refinery Wastewater with Scrap Iron. Water Air Soil Pollut. 2017, 228, 312. [CrossRef]

25. GilPavas, E.; Dobrosz-Gómez, I.; Gómez-García, M.-Á. Optimization and toxicity assessment of a combined electrocoagulation, $\mathrm{H}_{2} \mathrm{O}_{2} / \mathrm{Fe}^{2+} / \mathrm{UV}$ and activated carbon adsorption for textile wastewater treatment. Sci. Total Environ. 2019, 651, 551-560. [CrossRef] [PubMed]

26. Yin, R.; Shang, C. Removal of micropollutants in drinking water using UV-LED/chlorine advanced oxidation process followed by activated carbon adsorption. Water Res. 2020, 185, 116297. [CrossRef] [PubMed]

27. Lemus, J.; Martin-Martinez, M.; Palomar, J.; Gomez-Sainero, L.; Gilarranz, M.A.; Rodriguez, J.J. Removal of chlorinated organic volatile compounds by gas phase adsorption with activated carbon. Chem. Eng. J. 2012, 211-212, 246-254. [CrossRef]

28. Ebrahimi, M.; Schmitz, O.; Kerker, S.; Liebermann, F.; Czermak, P. Dynamic cross-flow filtration of oilfield produced water by rotating ceramic filter discs. Desalination Water Treat. 2013, 51, 1762-1768. [CrossRef]

29. Yuliwati, E.; Ismail, A.F.; Matsuura, T.; Kassim, M.A.; Abdullah, M.S. Effect of modified PVDF hollow fiber submerged ultrafiltration membrane for refinery wastewater treatment. Desalination 2011, 283, 214-220. [CrossRef]

30. Madaeni, S.S.; Ahmadi Monfared, H.; Vatanpour, V.; Arabi Shamsabadi, A.; Salehi, E.; Daraei, P.; Laki, S.; Khatami, S.M. Coke removal from petrochemical oily wastewater using $\gamma-\mathrm{Al}_{2} \mathrm{O}_{3}$ based ceramic microfiltration membrane. Desalination 2012, 293, 87-93. [CrossRef]

31. Ebrahimi, M.; Willershausen, D.; Ashaghi, K.S.; Engel, L.; Placido, L.; Mund, P.; Bolduan, P.; Czermak, P. Investigations on the use of different ceramic membranes for efficient oil-field produced water treatment. Desalination 2010, 250, 991-996. [CrossRef]

32. Elmaleh, S.; Ghaffor, N. Cross-flow ultrafiltration of hydrocarbon and biological solid mixed suspensions. J. Membr. Sci. 1996, 118, 111-120. [CrossRef]

33. Moslehyani, A.; Ismail, A.F.; Othman, M.H.D.; Matsuura, T. Design and performance study of hybrid photocatalytic reactorPVDF/MWCNT nanocomposite membrane system for treatment of petroleum refinery wastewater. Desalination 2015, 363, 99-111. [CrossRef]

34. Freeman, S.; Shorney-Darby, H. What's the Buzz about Ceramic Membranes? J. AWWA 2011, 103, 12-13. [CrossRef]

35. Valdés, H.; Zaror, C.A. Heterogeneous and homogeneous catalytic ozonation of benzothiazole promoted by activated carbon: Kinetic approach. Chemosphere 2006, 65, 1131-1136. [CrossRef]

36. Munirasu, S.; Haija, M.A.; Banat, F. Use of membrane technology for oil field and refinery produced water treatment-A review. Process Saf. Environ. Prot. 2016, 100, 183-202. [CrossRef]

37. Asatekin, A.; Mayes, A.M. Oil Industry Wastewater Treatment with Fouling Resistant Membranes Containing Amphiphilic Comb Copolymers. Environ. Sci. Technol. 2009, 43, 4487-4492. [CrossRef]

38. Howe, K.J.; Clark, M.M. Fouling of Microfiltration and Ultrafiltration Membranes by Natural Waters. Environ. Sci. Technol. 2002, 36, 3571-3576. [CrossRef]

39. Song, J.; Zhang, Z.; Zhang, X. A comparative study of pre-ozonation and in-situ ozonation on mitigation of ceramic UF membrane fouling caused by alginate. J. Membr. Sci. 2017, 538, 50-57. [CrossRef]

40. Song, J.; Zhang, Z.; Tang, S.; Tan, Y.; Zhang, X. Does pre-ozonation or in-situ ozonation really mitigate the protein-based ceramic membrane fouling in the integrated process of ozonation coupled with ceramic membrane filtration? J. Membr. Sci. 2018, 548, 254-262. [CrossRef]

41. Park, W.-I.; Jeong, S.; Im, S.-J.; Jang, A. High turbidity water treatment by ceramic microfiltration membrane: Fouling identification and process optimization. Environ. Technol. Innov. 2020, 17, 100578. [CrossRef]

42. Fan, X.; Tao, Y.; Wang, L.; Zhang, X.; Lei, Y.; Wang, Z.; Noguchi, H. Performance of an integrated process combining ozonation with ceramic membrane ultra-filtration for advanced treatment of drinking water. Desalination 2014, 335, 47-54. [CrossRef] 
43. Liu, J.; He, K.; Zhang, J.; Li, C.; Zhang, Z. Coupling ferrate pretreatment and in-situ ozonation/ceramic membrane filtration for wastewater reclamation: Water quality and membrane fouling. J. Membr. Sci. 2019, 590, 117310. [CrossRef]

44. Ahmad, R.; Guo, J.; Kim, J. Structural characteristics of hazardous organic dyes and relationship between membrane fouling and organic removal efficiency in fluidized ceramic membrane reactor. J. Clean. Prod. 2019, 232, 608-616. [CrossRef]

45. Liu, F.; Yao, H.; Sun, S.; Tao, W.; Wei, T.; Sun, P. Photo-Fenton activation mechanism and antifouling performance of an FeOCl-coated ceramic membrane. Chem. Eng. J. 2020, 402, 125477. [CrossRef]

46. Tang, S.; Zhang, L.; Peng, Y.; Liu, J.; Zhang, Z. Fenton cleaning strategy for ceramic membrane fouling in wastewater treatment. J. Environ. Sci. 2019, 85, 189-199. [CrossRef] [PubMed]

47. Baker, A.; Inverarity, R.; Charlton, M.; Richmond, S. Detecting river pollution using fluorescence spectrophotometry: Case studies from the Ouseburn, NE England. Environ. Pollut. 2003, 124, 57-70. [CrossRef]

48. Coble, P.G. Characterization of marine and terrestrial DOM in seawater using excitation-emission matrix spectroscopy. Mar. Chem. 1996, 51, 325-346. [CrossRef]

49. Zhang, J.; Song, F.; Li, T.; Xie, K.; Yao, H.; Xing, B.; Li, Z.; Bai, Y. Simulated photo-degradation of dissolved organic matter in lakes revealed by three-dimensional excitation-emission matrix with regional integration and parallel factor analysis. J. Environ. Sci. 2020, 90, 310-320. [CrossRef]

50. Divya, O.; Mishra, A.K. Understanding the concept of concentration-dependent red-shift in synchronous fluorescence spectra: Prediction of $\lambda$ SFSmax and optimization of $\Delta \lambda$ for synchronous fluorescence scan. Anal. Chim. Acta 2008, 630, 47-56. [CrossRef] [PubMed]

51. Wang, Z.-P.; Zhang, T. Characterization of soluble microbial products (SMP) under stressful conditions. Water Res. 2010, 44, 5499-5509. [CrossRef]

52. Smith, G.C.; Sinski, J.F. The Red-Shift Cascade: Investigations into the Concentration-Dependent Wavelength Shifts in Three-Dimensional Fluorescence Spectra of Petroleum Samples. Appl. Spectrosc. 1999, 53, 1459-1469. [CrossRef]

53. Abouleish, M.Y.Z.; Wells, M.J.M. Trihalomethane formation potential of aquatic and terrestrial fulvic and humic acids: Sorption on activated carbon. Sci. Total Environ. 2015, 521-522, 293-304. [CrossRef]

54. Huang, S.; Gan, W.; Yan, M.; Zhang, X.; Zhong, Y.; Yang, X. Differential UV-vis absorbance can characterize the reaction of organic matter with $\mathrm{ClO}_{2}$. Water Res. 2018, 139, 442-449. [CrossRef]

55. Li, J.; Tong, Y.; Guan, L.; Wu, S.; Li, D. Optimization of COD determination by UV-vis spectroscopy using PLS chemometrics algorithms. Optik 2018, 174, 591-599. [CrossRef]

56. Chen, J.; Mu, L.; Jiang, B.; Yin, H.; Song, X.; Li, A. TG/DSC-FTIR and Py-GC investigation on pyrolysis characteristics of petrochemical wastewater sludge. Bioresour. Technol. 2015, 192, 1-10. [CrossRef]

57. Ratman, I.; Kusworo, T.D.; Utomo, D.P.; Azizah, D.A.; Ayodyasena, W.A. Petroleum Refinery Wastewater Treatment using Three Steps Modified Nanohybrid Membrane Coupled with Ozonation as Integrated Pre-treatment. J. Environ. Chem. Eng. 2020, 8, 103978. [CrossRef]

58. Lehman, S.G.; Liu, L. Application of ceramic membranes with pre-ozonation for treatment of secondary wastewater effluent. Water Res. 2009, 43, 2020-2028. [CrossRef]

59. Zhang, W.; Luo, J.; Ding, L.; Jaffrin, M.Y. A Review on Flux Decline Control Strategies in Pressure-Driven Membrane Processes. Ind. Eng. Chem. Res. 2015, 54, 2843-2861. [CrossRef]

60. Cui, Z.; Peng, W.; Fan, Y.; Xing, W.; Xu, N. Effect of Cross-flow Velocity on the Critical Flux of Ceramic Membrane Filtration as a Pre-treatment for Seawater Desalination. Chin. J. Chem. Eng. 2013, 21, 341-347. [CrossRef]

61. Her, N.; Amy, G.; Chung, J.; Yoon, J.; Yoon, Y. Characterizing dissolved organic matter and evaluating associated nanofiltration membrane fouling. Chemosphere 2008, 70, 495-502. [CrossRef]

62. Li, C.; Li, X.; Qin, L.; Wu, W.; Meng, Q.; Shen, C.; Zhang, G. Membrane photo-bioreactor coupled with heterogeneous Fenton fluidized bed for high salinity wastewater treatment: Pollutant removal, photosynthetic bacteria harvest and membrane antifouling analysis. Sci. Total Environ. 2019, 696, 133953. [CrossRef]

63. Peres, J.A.; Beltrán de Heredia, J.; Domínguez, J.N.R. Integrated Fenton's reagent-Coagulation/flocculation process for the treatment of cork processing wastewaters. J. Hazard. Mater. 2004, 107, 115-121. [CrossRef]

64. Teng, C.; Zhou, K.; Zhang, Z.; Peng, C.; Chen, W. Elucidating the structural variation of membrane concentrated landfill leachate during Fenton oxidation process using spectroscopic analyses. Environ. Pollut. 2020, 256, 113467. [CrossRef] [PubMed]

65. Field, R.W.; Pearce, G.K. Critical, sustainable and threshold fluxes for membrane filtration with water industry applications. Adv. Colloid Interface Sci. 2011, 164, 38-44. [CrossRef]

66. Field, R.W.; Wu, D.; Howell, J.A.; Gupta, B.B. Critical flux concept for microfiltration fouling. J. Membr. Sci. 1995, 100, $259-272$. [CrossRef]

67. Kumar, R.V.; Goswami, L.; Pakshirajan, K.; Pugazhenthi, G. Dairy wastewater treatment using a novel low cost tubular ceramic membrane and membrane fouling mechanism using pore blocking models. J. Water Process Eng. 2016, 13, 168-175. [CrossRef]

68. Lee, S.-J.; Dilaver, M.; Park, P.-K.; Kim, J.-H. Comparative analysis of fouling characteristics of ceramic and polymeric microfiltration membranes using filtration models. J. Membr. Sci. 2013, 432, 97-105. [CrossRef] 